\title{
Global Change Biology
}

\section{Weakened growth of cropland N2O emissions in China associated with nationwide policy interventions}

\begin{tabular}{|c|c|}
\hline Journal: & Global Change Biology \\
\hline Manuscript ID & Draft \\
\hline Wiley - Manuscript type: & Primary Research Articles \\
\hline $\begin{array}{r}\text { Date Submitted by the } \\
\text { Author: }\end{array}$ & $n / a$ \\
\hline Complete List of Authors: & $\begin{array}{l}\text { Shang, Ziyin; Peking University, Sino-France Institute of Earth Systems } \\
\text { Science, Laboratory for Earth Surface Processes, College of Urban and } \\
\text { Environmental Sciences; University of Aberdeen, Institute of Biological } \\
\text { and Environmental Science } \\
\text { Zhou, Feng; Peking University, Ecology } \\
\text { Smith, Pete; University of Aberdeen, Institute of Biological and } \\
\text { Environmental Science } \\
\text { Saikawa, Eri ; Emory University, Department of Environmental Sciences } \\
\text { Ciais, Philippe; Laboratory for Climate Sciences and the Environment } \\
\text { (LSCE) } \\
\text { CHANG, Jinfeng; Laboratory for Climate Sciences and the Environment } \\
\text { (LSCE) } \\
\text { Tian, Hanqin; Auburn University, School of Forestry and Wildlife Sciences } \\
\text { Del Grosso, Stephen J; USDA ARS, Soil Management and Sugar Beet } \\
\text { Research } \\
\text { Ito, Akihiko; National Institute for Environmental Studies, Center for } \\
\text { Global Environmental Research } \\
\text { Chen, Minpeng; Renmin University of China, School of Agricultural } \\
\text { Economics and Rural Development } \\
\text { Wang, Qihui; Peking University, Sino-France Institute of Earth Systems } \\
\text { Science, Laboratory for Earth Surface Processes, College of Urban and } \\
\text { Environmental Sciences } \\
\text { BO, YAN; Peking University } \\
\text { Cui, Xiaoqing; Peking University, Sino-France Institute of Earth Systems } \\
\text { Science, Laboratory for Earth Surface Processes, College of Urban and } \\
\text { Environmental Sciences } \\
\text { Castaldi, Simona; Universita degli Studi della Campania Luigi Vanvitelli, } \\
\text { Dipartimento di Scienze e Tecnologie Ambientali Biologiche e } \\
\text { Farmaceutiche } \\
\text { Juszczak, Radoslaw; Poznan University of Life Sciences, Department of } \\
\text { Meteorology } \\
\text { Kasimir, Asa; University of Gothenburg, Department of Earth Sciences } \\
\text { Magliulo, Vincenzo; National Research Council of Italy, Institute for } \\
\text { Mediterranean Agriculture and Forest Systems } \\
\text { Medinets, Sergiy; Odessa National I. I. Mechnikov University, Regional } \\
\text { Centre for Integrated Environmental Monitoring and Ecological Studies } \\
\text { Medinets, Volodymyr; Odessa National I.I. Mechnikov University, } \\
\text { Regional Centre for Integrated Environmental Monitoring and Ecological } \\
\text { Studies } \\
\text { Rees, Bob; Scotland's Rural College }\end{array}$ \\
\hline
\end{tabular}




\begin{tabular}{|c|c|}
\hline & $\begin{array}{l}\text { Wohlfahrt, Georg; University of Innsbruck, Institute of Ecology } \\
\text { Sabbatini, Simone; University of Tuscia, DIBAF }\end{array}$ \\
\hline Keywords: & $\begin{array}{l}\text { Nitrous oxide, agricultural soils, emission inventory, flux upscaling, } \\
\text { agricultural management, process-based model, temporal trend, spatial } \\
\text { pattern }\end{array}$ \\
\hline Abstract: & 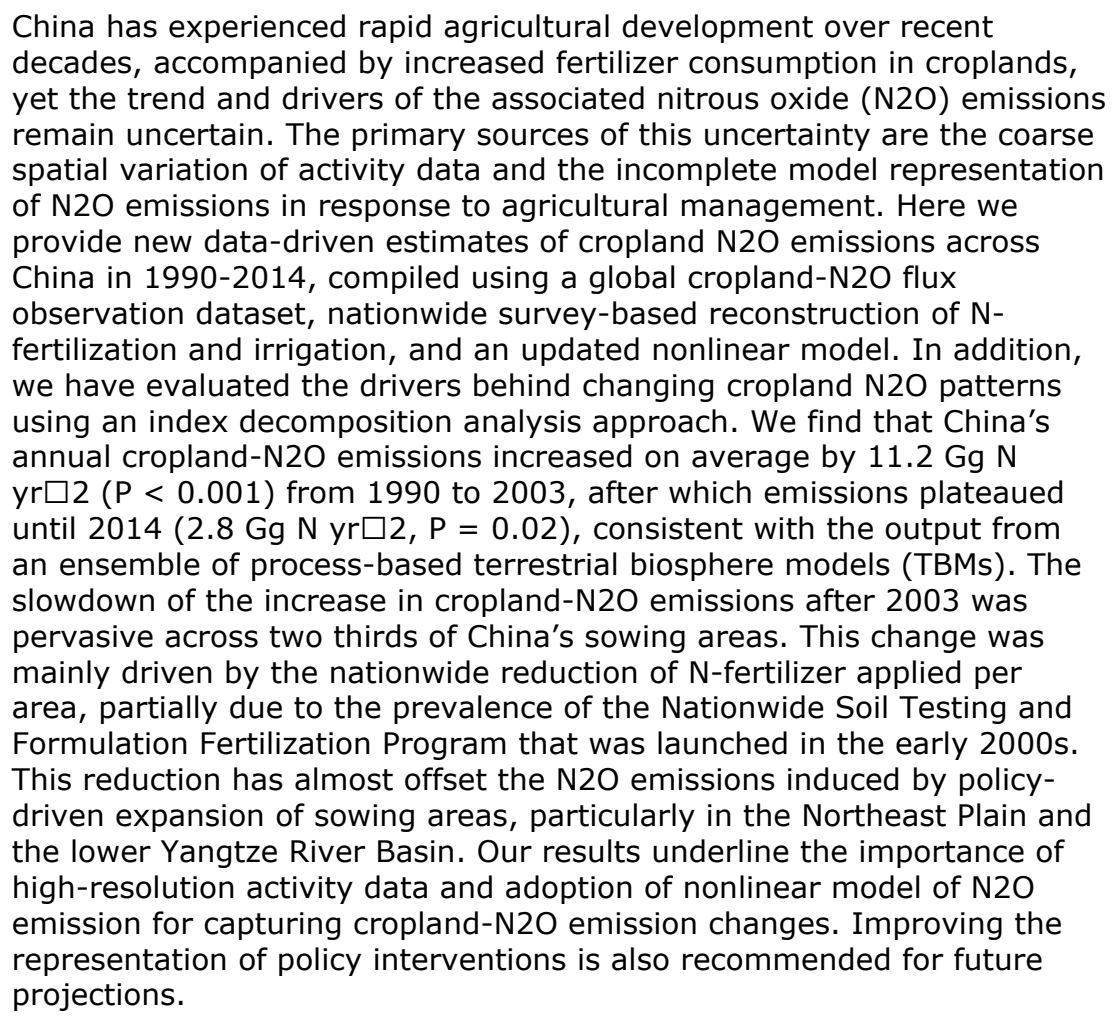 \\
\hline
\end{tabular}


1 Weakened growth of cropland $\mathrm{N}_{2} \mathrm{O}$ emissions in China associated 2 with nationwide policy interventions

3 Ziyin Shang ${ }^{1,2}$, Feng Zhou ${ }^{1 *}$, Pete $\mathrm{Smith}^{2}$, Eri Saikawa ${ }^{3}$, Philippe Ciais ${ }^{4}$, Jinfeng Chang ${ }^{4}$, Hanqin Tian , 4 Stephen J. Del Grosso ${ }^{6}$, Akihiko Ito ${ }^{7}$, Minpeng Chen ${ }^{8}$, Qihui Wang ${ }^{1}$, Yan Bo ${ }^{1}$, Xiaoqing Cui ${ }^{1}$, Simona 5 Castaldi $^{9}$, Radoslaw Juszczak ${ }^{10}$, Åsa Kasimir ${ }^{11}$, Enzo Magliulo ${ }^{12}$, Sergiy Medinets ${ }^{13}$, Volodymyr Medinets ${ }^{13}$, 6 Robert M. Rees ${ }^{14}$, Georg Wohlfahrt ${ }^{15}$, Simone Sabbatini ${ }^{16}$

7

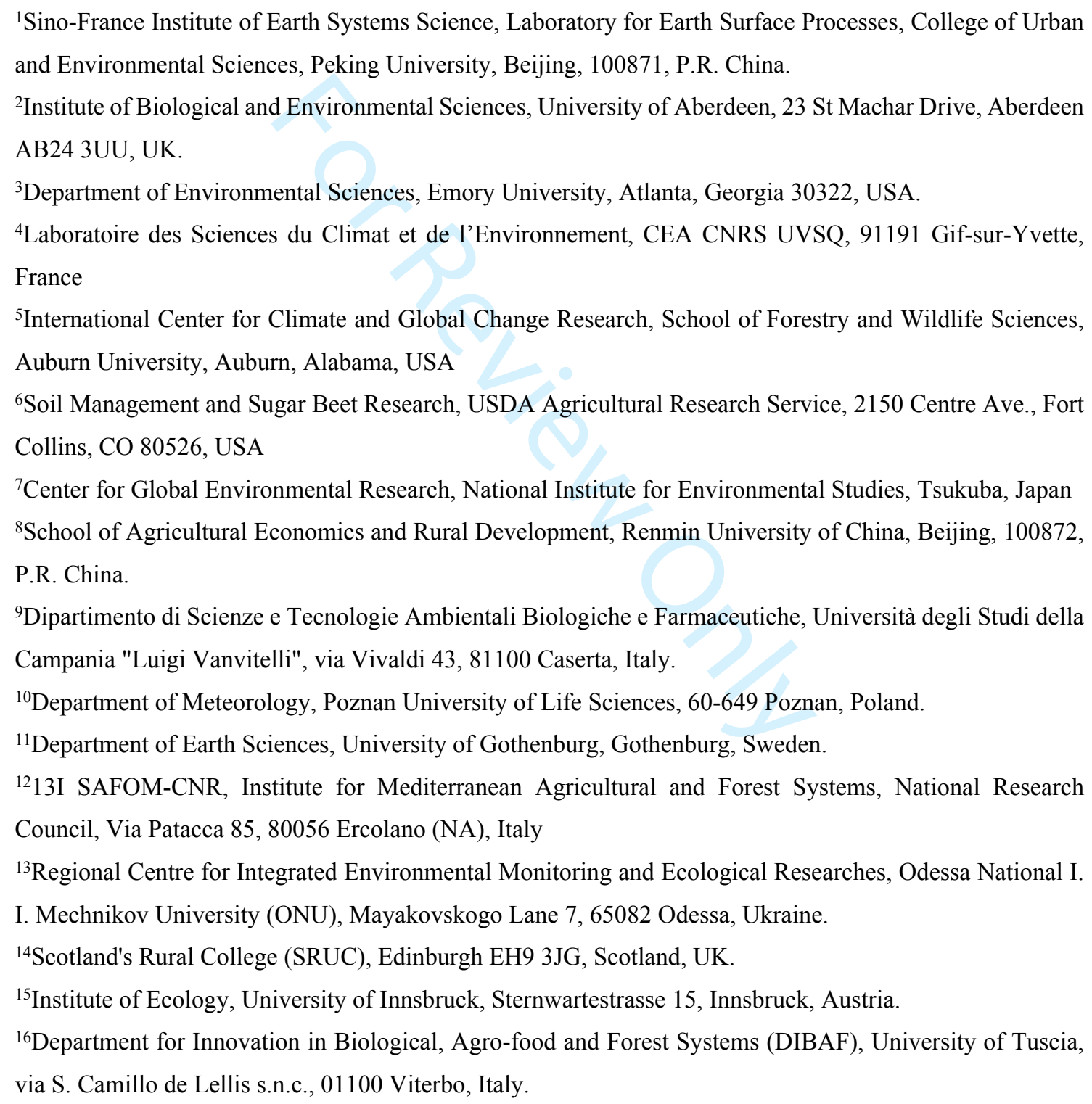

\section{*Corresponding Author}

Phone: +86 10 62756511, Fax: +86 10 62756560; Email: zhouf@pku.edu.cn. 


\section{ABSTRACT}

38 China has experienced rapid agricultural development over recent decades, accompanied by increased fertilizer consumption in croplands, yet the trend and drivers of the associated nitrous oxide $\left(\mathrm{N}_{2} \mathrm{O}\right)$ emissions remain uncertain. The primary sources of this uncertainty are the coarse spatial variation of activity data and the incomplete model representation of $\mathrm{N}_{2} \mathrm{O}$ emissions in $\mathrm{N}_{2} \mathrm{O}$ emissions across China in 1990-2014, compiled using a global cropland- $\mathrm{N}_{2} \mathrm{O}$ flux observation dataset, nationwide survey-based reconstruction of $\mathrm{N}$-fertilization and irrigation, and an updated nonlinear model. In addition, we have evaluated the drivers behind changing cropland $\mathrm{N}_{2} \mathrm{O}$ patterns using an index decomposition analysis approach. We find that China's annual cropland $-\mathrm{N}_{2} \mathrm{O}$ emissions increased on average by $11.2 \mathrm{Gg} \mathrm{N} \mathrm{yr}^{-2}(P<0.001)$ from 1990 to 2003 , after which emissions plateaued until 2014 (2.8 $\left.\mathrm{Gg} \mathrm{N} \mathrm{yr}^{-2}, P=0.02\right)$, consistent with the output from an ensemble of process-based terrestrial biosphere models (TBMs). The slowdown of the increase in cropland $-\mathrm{N}_{2} \mathrm{O}$ emissions after 2003 was pervasive across two thirds of China's sowing areas. This change was mainly driven by the nationwide reduction of $\mathrm{N}$-fertilizer applied per area, partially due to the prevalence of the Nationwide Soil Testing and Formulation Fertilization Program that was launched in the early 2000s. This reduction has almost offset the $\mathrm{N}_{2} \mathrm{O}$ emissions induced by policy-driven expansion of sowing areas, particularly in the Northeast Plain and the lower Yangtze River Basin. Our results underline the importance of high-resolution activity data and adoption of nonlinear model of $\mathrm{N}_{2} \mathrm{O}$ emission for capturing cropland $-\mathrm{N}_{2} \mathrm{O}$ emission changes. Improving the representation of policy interventions is also recommended for future projections. 
59 Keywords: Nitrous oxide; agricultural soils; emission inventory; flux upscaling; agricultural 60 management; process-based model; temporal trend; spatial pattern 


\section{1. Introduction}

62 Nitrous oxide $\left(\mathrm{N}_{2} \mathrm{O}\right)$ is a potent greenhouse gas, with a global warming potential 265 298 times 63 greater than that of $\mathrm{CO}_{2}$ over a 100-year time horizon (Myhre et al., 2013). Its emissions are 64 recognized as the most important ozone-depleting substance (Ravishankara, Daniel, \& 65 Portmann, 2009). Accumulating evidence points to croplands as the largest global source $66(>40 \%)$ of anthropogenic $\mathrm{N}_{2} \mathrm{O}$ (Paustian et al., 2016). Global cropland $\mathrm{N}_{2} \mathrm{O}$ emissions are 67 projected to increase by $\sim 50 \%$ from 2010 to 2050 , due to the future intensification and expansion of cropland production (Alexandratos \& Bruinsma, 2012). Reducing cropland $\mathrm{N}_{2} \mathrm{O}$ emissions is a key mitigation option for limiting climate warming, especially in relation to recently developed policy objectives relating to climate change and concerns regarding ozone depletion (Allen et al. 2018). However, high spatial and temporal variability makes the estimation of cropland $\mathrm{N}_{2} \mathrm{O}$ emissions notoriously difficult (e.g., quantity, pattern, trend) (Paustian et al., 2016), resulting in large discrepancies between bottom-up and top-down approaches (Tian et al., 2016).

One of the sources of uncertainty is the model structure of bottom-up approaches that consider a linear response of $\mathrm{N}_{2} \mathrm{O}$ emissions to $\mathrm{N}$ application rate, as recommended in the Tier 1 method for a national $\mathrm{N}_{2} \mathrm{O}$ inventory by the Intergovernmental Panel on Climate Change (IPCC, 2006). Recent synthesis of field observations suggests that $\mathrm{N}_{2} \mathrm{O}$ emissions respond nonlinearly to an increasing N application rate (Philibert, Loyce, \& Makowski, 2012; Shcherbak, Millar, \& Robertson, 2014; Song et al. 2018) This nonlinear response was partially ascribed to the fact that high ammonium ion concentrations from urea hydrolysis inhibits nitrite transformation to nitrate (Ma, Shan, \& Yan, 2015), resulting in nitrite accumulation which is subsequently emitted as $\mathrm{N}_{2} \mathrm{O}$. Philibert et al. (2012) proposed a nonlinear model with fixed parameters, which improved the predictive performance of $\mathrm{N}_{2} \mathrm{O}$ flux. This model was further improved by using 
random parameters from a more recent and a larger field observation dataset of $\mathrm{N}_{2} \mathrm{O}$ flux (Gerber et al., 2016). In addition to the nonlinear response of emissions to $\mathrm{N}$ inputs, microbially-mediated $\mathrm{N}_{2} \mathrm{O}$ is also strongly dependent on climate and soil properties (Perlman, Hijmans, \& Horwath, 2014). A spatially-referenced nonlinear model was therefore developed to simulate $\mathrm{N}_{2} \mathrm{O}$ emissions in response to fertilizer $\mathrm{N}$ application rate $\left(\mathrm{N}_{\text {rate }}\right)$ under various environmental or management-related conditions (Zhou et al., 2015). Comparison between models showed that such models outperformed nonlinear models with fixed or random parameters (Zhou et al., 2015).

The accuracy of simulating $\mathrm{N}_{2} \mathrm{O}$ emissions is dependent on the representation of model parameters and the spatial aggregation of agricultural activity data. For example, a spatiallyreferenced nonlinear model (Zhou et al., 2015) calibrated against observations in China was able to better capture the variations of $\mathrm{N}_{2} \mathrm{O}$ emissions on sites with similar conditions to the calibration dataset, but was unable to reproduce emissions at other sites. To improve the performance of diagnostic models at a regional scale, field observations representative of a wide range of environmental and management-related variables are required. In addition, $\mathrm{N}_{2} \mathrm{O}$ emission models are sensitive to the degree of spatial aggregation in fertilizer and irrigation data. Uncertainty of input data is expected to increase with decreasing spatial scale without altering spatial differences in fertilizer and irrigation applications (Gerber et al., 2016). Although the spatial resolution of management-related data is improving, mainly by evenly disaggregating national-scale data into gridded maps (Lu \& Tian, 2017; Zhang et al., 2017), long-term, high-resolution maps of cropland-specific $\mathrm{N}$-fertilizers and irrigation inputs are not yet available at the global or regional scale.

China is currently the largest emitters of anthropogenic $\mathrm{N}_{2} \mathrm{O}$ emissions globally (Zhou et al., 
111 2014). Over the past decades, this source in China increased with N-fertilizer use, accounting 112 for over $20 \%$ of global cropland $-\mathrm{N}_{2} \mathrm{O}$ emissions from IPCC Tier 1 inventories (FAO, 2018; Janssens-Maenhout et al., 2019; Winiwarter, Höglund-Isaksson, Klimont, Schöpp, \& Amann, 2018). China is a large country with contrasting crop production systems, climate and soil types, where the patterns of $\mathrm{N}_{2} \mathrm{O}$ emissions are poorly understood compared to some developed countries (Zou et al., 2010; Zhou et al., 2015; Yue et al., 2018). In the last decade, processbased models (e.g., DNDC, DAYCENT, DLEM), used to produce Tier 3 IPCC estimates, simulated global and regional cropland $-\mathrm{N}_{2} \mathrm{O}$ emissions using sub-national $\mathrm{N}$ inputs from China (Li et al, 2001; Tian et al., 2019; Yue et al., 2019). These models are arguably more realistic than the Tier 1 approach because they account for climatic and soil variabilities. Although multi-model ensemble may reduce some errors across individual models through a broader integration of model processes (Tian et al., 2019), these individual models have rarely been validated by observations across contrasting environmental and management-related conditions (Ehrhardt et al., 2017), leading to large uncertainties not only in estimating emission trends, but also in identifying underlying drivers.

To address these knowledge gaps, we re-estimate the spatial pattern and temporal trend of cropland $\mathrm{N}_{2} \mathrm{O}$ emissions across China in 1990-2014. We advance the estimation of spatiallyexplicit, long-term cropland $\mathrm{N}_{2} \mathrm{O}$ emissions in China by using an updated version of the spatially-referenced nonlinear model (Zhou et al., 2015) with high-resolution, crop-specific gridded datasets of $\mathrm{N}$-fertilizer and irrigation uses. First, the model was updated through recalibration with $\mathrm{N}_{2} \mathrm{O}$ emission observations three times more than previous dataset. Second, maps (1-km) of crop-specific $\mathrm{N}$-fertilization and irrigation application rates across Chin were collated, based on a compilation of sub-national statistics or surveys (Zhou et al., 2014; Zou et al. 2018), which differ from previous datasets based on downscaling of national totals (Lu \& 
136 Tian, 2017; Janssens-Maenhout et al., 2017) or modeling (Flörke, Schneider, \& McDonald, 137 2018). Finally, using one type of index decomposition analysis (Ang, 2015), we separated the

contributions of agricultural management practices and environmental conditions on cropland $\mathrm{N}_{2} \mathrm{O}$ emission trends. This study considers direct emissions from croplands where synthetic fertilizers, livestock manure, human excreta, and crop residues are added, as well as indirect emissions due to atmospheric $\mathrm{N}$ deposition. Indirect emissions due to $\mathrm{N}$ leaching or runoff are not considered.

\section{Data and methods}

\subsection{Updated spatially-referenced nonlinear model (SRNM)}

The previous version of the SRNM model (Zhou et al., 2015) assume a quadratic relationship between cropland $\mathrm{N}$ application rates and $\mathrm{N}_{2} \mathrm{O}$ emissions, with spatially-variable model parameters depending on climate, soil properties, and crop management practices. The SRNM predict cropland $-\mathrm{N}_{2} \mathrm{O}$ emissions for each of geographical grids rather than administrative units. This calibrated formulation of $\mathrm{N}_{2} \mathrm{O}$ emissions was found to explain over $84 \%$ of the variance of field observations (Zhou et al., 2015), yet the model was only constrained by 732 field observations of $\mathrm{N}_{2} \mathrm{O}$ emissions. We updated the model by fitting the $\mathrm{N}_{2} \mathrm{O}$ emissions to new observations extended to 2,740 flux observations across 345 sites in the world (see Text S1, Tables S1 S2). The extended dataset covers a wider range of environmental conditions and agricultural management practices compared to our previous work and other similar studies (Gerber et al., 2016; Shcherbak et al., 2014) (Tables S3). The $\mathrm{N}_{2} \mathrm{O}$ emissions $(E)$ of the updated SRNM model is described as:

$$
E_{i j t}=\alpha_{i j} R_{i j t}^{2}+\beta_{i j} R_{i j t}+\gamma_{i j}+\varepsilon_{i j t},
$$

where 
160

161

$$
\begin{gathered}
\alpha_{i j} \sim N\left(X_{k}^{T} \lambda_{i j k}, \sigma_{i j k}^{2}\right), \beta_{i j} \sim N\left(X_{k}^{T} \phi_{i j k}, \sigma_{i j k}^{\prime 2}\right), \gamma_{i j} \sim N\left(X_{k}^{T} \varphi_{i j k}, \sigma_{i j k}^{\prime 2}\right), \\
\lambda_{i j k} \sim N\left(\mu_{i j k}, \omega_{i j k}^{2}\right), \phi_{i j k} \sim N\left(\mu_{i j k}^{\prime}, \omega_{i j k}^{\prime 2}\right), \varphi_{i j k} \sim N\left(\mu_{i j k}^{\prime \prime}, \omega_{i j k}^{\prime 2}\right), \varepsilon_{i j t} \sim N\left(0, \tau^{2}\right),
\end{gathered}
$$

and $i$ denotes the sub-function of $\mathrm{N}_{2} \mathrm{O}$ emissions $(\mathrm{i}=1,2, \ldots, I), j$ represents the type of crop (j=1-9, i.e., represents maize, wheat, paddy rice, vegetables, fruits, potatoes, oil crops, legume, and the other crops). $k$ is the index of climate factors or soil property $(k=1-6$, i.e., soil organic carbon content, clay content, bulk density, soil $\mathrm{pH}$, air temperature and the sum of precipitation and irrigation). $E_{i j t}$ denotes the $\mathrm{N}_{2} \mathrm{O}$ emission rate $\left(\mathrm{kg} \mathrm{N} \mathrm{ha}^{-1} \mathrm{yr}^{-1}\right)$ predicted for crop type $j$ in year $t$ in the $i$ th type of regions. $R_{i j t}$ is $\mathrm{N}$ application rate $\left(\mathrm{kg} \mathrm{N} \mathrm{ha}^{-1} \mathrm{yr}^{-1}\right) . \alpha, \beta$, and $\gamma$ are described as linear functions of climate or soil factors $X_{k}$ (Table S2). $\gamma$ is an intercept denoting the background emission, $\alpha R^{2}+\beta R$ represents the fertilizer-induced emission, $\alpha R+\beta$ being the emission factor, and $\varepsilon$ is the residual term. The random terms $\lambda, \phi, \varphi$, and $\varepsilon$ are assumed to be independent and normally distributed. $\mu$ is the mean applied $\mathrm{N}$ effect for $\alpha$ and $\beta$ or the mean emission baseline for $\gamma . \sigma, \omega$, and $\tau$ are standard deviations. All the parameter mean values and standard deviations in each of sub-functions were estimated by the Bayesian Recursive Regression Tree version 2 (BRRT v2) (Zhou et al., 2015), constrained by the extended dataset. The estimated parameter values are presented in Table S4. The detailed methodology of the BRRT v2 algorithm and the associated procedures can be found in Zhou et al. (2015).

\subsection{New model inputs of $\mathrm{N}$-fertilizers and irrigation}

The updated SRNM model is forced by multiple gridded input datasets, including new datasets describing $\mathrm{N}$ inputs and irrigation to croplands. For $\mathrm{N}$ inputs, we first collected nationwide surveys of county-scale (the third-level administrative division) synthetic $\mathrm{N}$ fertilizer applied to croplands $\left(F_{S N}, \mathrm{~kg} \mathrm{~N} \mathrm{yr}^{-1}\right)$ for $\sim 2900$ counties in Mainland China, Taiwan, Hong Kong, and Macau for the period 1990-2014. These data were further disaggregated by nine types of crop, 
184 based on the crop-specific, provincial data of $R_{i j t}$ from the Statistics of Cost and Income of 185 Chinese Farm Produce (http://tongji.cnki.net/overseas). In addition, China has experienced changes of County-scale administrative divisions, such as aggregation, disaggregation, and name changes, so we harmonized the temporal evolution of $F_{S N}$ to fit the latest administrative divisions (http://geodata.pku.edu.cn), based on the historical trajectories summarized by the Ministry of Civil Affairs of China (http://xzqh.mca.gov.cn/). More details can be found in Text S2. Second, we estimated annual $\mathrm{N}$ in livestock manure, human excreta, and crop residues returned to croplands by the Eubolism model at county scale (Chen, Chen, \& Sun, 2010), based on county-scale activity data, such as the numbers of livestock by animal, rural population, and yields by crop type. The Eubolism model has been evaluated against multi-site observations in highly-fertilized cropping areas across China (see Text S3). Third, dry and wet deposition of $\mathrm{N}$ species were quantified by the global aerosol chemistry climate model LMDZ-OR-INCA at a horizontal resolution of $1.27^{\circ}$ latitude by $2.5^{\circ}$ longitude (Wang et al., 2017), in which wet $\mathrm{N}$ deposition fluxes have been validated by a recent global dataset (Vet et al., 2014). Finally, cropspecific $\mathrm{N}$ application rates $\left(R_{i j t}\right)$ were calculated as county-scale $\mathrm{N}$ input totals (i.e., synthetic fertilizers, manure, human excreta, crop residues, and $\mathrm{N}$ depositions) divided by the associated sowing areas that were obtained from the statistical yearbooks of 31 provinces (http://tongji.cnki.net/overseas). This new county-scale dataset of $R_{i j t}$ was then resampled into a 1-km grid map based on the dynamic cropland distributions (Liu et al., 2014). We assumed a maximum $\mathrm{N}$ fertilizer application rate of $700 \mathrm{~kg} \mathrm{~N} \mathrm{ha}^{-1}$ based on a previous study (Carlson et al., 2017).

The second new gridded dataset is cropland irrigation application rate for the period 1990-2014. We first collected prefectural-level (i.e., the second-level administrative division) cropland irrigation amounts from two nationally-coordinated surveys: the $2^{\text {nd }}$ National Water Resources 
209 Assessment Program for the period 1990-2000 (China Renewable Energy Engineering Insitute, 210 2014) and the Water Resources Bulletins of 31 provinces for the rest of period 2001-2014 211 (www.mwr.gov.cn/english/publs/). Both surveys had an identical methodology, including definitions, survey units, field surveys or measurements, and quality assurance. The detailed survey methodology is described in Text S4. It should be noted that cropland irrigation used here did not include water applied for aquaculture that accounts for less than $5 \%$ of agricultural irrigation (Zhu, Li, Li, Pan, \& Shi, 2013). Cropland irrigation rates $\left(\mathrm{mm} \mathrm{yr}^{-1}\right)$ at the prefectural level were then calculated as cropland irrigation amounts divided by sowing areas. Similarly with $R_{i j t}$, these prefectural-scale cropland irrigation application rates were then disaggregated by resampling to 1-km gridded cropland maps for the period 1990-2014, and such rates were simply assumed same for each crop. Other data sources for model inputs can be found in Text $\mathrm{S} 5$, including soil properties and climate factors relevant to $\mathrm{N}_{2} \mathrm{O}$ emissions.

\subsection{Model validation and comparison}

Process-based models were run using the same input data, and their outputs were compared with the results of the updated SRNM model. These process-based models include the Dynamic Land Ecosystem Model (DLEM) (Tian et al., 2015), the Organising Carbon and Hydrology In Dynamic Ecosystems (ORCHIDEE-OCN) (Zaehle \& Friend, 2010), the Daily Century Model (DAYCENT) (Del Grosso et al., 2009), and Vegetation-Integrated Simulator for Trace Gases (VISIT) (Ito \& Inatomi, 2012). Nitrification and denitrification processes in these models are expressed as functions of available substrates $(\mathrm{NH}+4$ or $\mathrm{NO}-3$ concentration), reaction rates, soil temperature and water content, but with different formulations and parameterizations (Tian et al., 2018). The results from atmospheric inversion of Saikawa et al. (2014), constrained by global measurements of $\mathrm{N}_{2} \mathrm{O}$ atmospheric concentrations, were also compared with the estimated $\mathrm{N}_{2} \mathrm{O}$ emissions. The new inversion was also conducted by replacing emissions from 
this study for a priori agricultural soil emissions for China in the Bayesian inversion model (Saikawa et al., 2014). The detailed methodology and parameter calibration of the processbased models and the inversion model can be found in previous studies (Saikawa et al., 2014; Tian et al., 2018). In addition, the national estimates of cropland $\mathrm{N}_{2} \mathrm{O}$ emissions were compared with the state-of-the-art emission inventories, including the Food and Agriculture Organization Emission Database (FAOSTAT) (FAO, 2018), the Emissions Database for Global Atmospheric Research (EDGAR version 4.3.2) (Janssens-Maenhout et al., 2019), and the Greenhouse Gas and Air Pollution Interactions and Synergies (GAINS) (Winiwarter, HöglundIsaksson, Klimont, Schöpp, \& Amann, 2018), U.S. Environmental Protection Agency (USEPA) report (USEPA, 2012), and three China's National Communication Reports (CNCR; National Development and Reform Commission, 2017) submitted to the UNFCCC for years 1994, 2005, and 2012. Note that EDGAR, FAOSTAT and GAINS estimates were derived using the methodology of the 2006 IPCC Guidelines for National Greenhouse Gas Inventories (IPCC, 2006) and national fertilizer data from the FAO.

\subsection{Attribution of $\mathrm{N}_{2} \mathrm{O}$ emission trends}

We applied the Logarithmic Mean Divisia Index (LMDI) (Ang, 2015; Guan et al., 2018) to attribute $\mathrm{N}_{2} \mathrm{O}$ emission trends to different driving factors. The LMDI was chosen because of its path independence, consistency in aggregation, and ability to handle zero values (Ang, 2015). The LMDI analysis compares a set of driving factors between the base and final year of a given period, and explores the effects of these factors on the change in China's cropland- $\mathrm{N}_{2} \mathrm{O}$ emissions over that period. The detailed methodology of LMDI can be found in Ang (2015). According to previous modeling studies (Guan et al., 2018), we decomposed cropland- $\mathrm{N}_{2} \mathrm{O}$ emissions into a combination of different drivers: total sowing area $\left(A_{k}\right.$, ha), the share of nine different crops to total sowing area $\left(m_{j k}, \%\right)$ also known as crop mix, $\mathrm{N}$ application rate $\left(R_{j k}, \mathrm{~kg}\right.$ 
$\left.259 \mathrm{~N} \mathrm{ha}^{-1} \mathrm{yr}^{-1}\right)$, and the emission intensity $\left(e_{j k}, \%\right)$ per crop type and region:

$$
E_{k}=\sum_{j}\left(A_{k} \times \frac{A_{j k}}{A_{k}} \times \frac{N_{j k}}{A_{j k}} \times \frac{E_{j k}}{N_{j k}}\right)=\sum_{j}\left(A_{k} \times m_{j k} \times R_{j k} \times e_{j k}\right),
$$

where region $k=1-8$ corresponds to China, the Northwest, the Northeast Plain, the North China Plain, the lower reach of Yangtze River basin, the Southwest, the Northwest, and QinghaiTibet Plateau; $A_{j k}$ is the sowing area of crop $j$ in cropping region $k ; N_{j k}$ and $E_{j k}$ are $\mathrm{N}$-fertilizer application amount and croplands $\mathrm{N}_{2} \mathrm{O}$ emission of crop $j$ in cropping region $k$, respectively. It should be noted that $e_{j k}$ is defined as cropland- $\mathrm{N}_{2} \mathrm{O}$ emission per unit of $N_{j k}$, which is different from the emission factor defined in the 2006 IPCC Guidelines, and represents the gross emission intensity at a given $\mathrm{N}$ application level. The change of $E$ of region $k$ in the year $t$ compared to the year $t-1$ is computed as

$$
\begin{aligned}
\Delta E_{k} & =\sum_{j} w_{j k} \ln \left(\frac{A_{k}^{t}}{A_{k}^{t-1}}\right)+\sum_{j} w_{j k} \ln \left(\frac{a_{j k}^{t}}{a_{j k}^{t-1}}\right)+\sum_{j} w_{j k} \ln \left(\frac{R_{j k}^{t}}{R_{j k}^{t-1}}\right)+\sum_{j} w_{j k} \ln \left(\frac{e_{j k}^{t}}{e_{j k}^{t-1}}\right) . \\
& =\Delta E_{A}+\Delta E_{m}+\Delta E_{R}+\Delta E_{e}
\end{aligned}
$$

Here, $w_{j k}=\left(E_{j k}^{t}-E_{j k}^{t-1}\right) /\left(\ln E_{j k}^{t}-\ln E_{j k}^{t-1}\right)$ is a weighting factor called the logarithmic mean weight (Ang, 2015). $\Delta E_{A}, \Delta E_{m}, \Delta E_{R}$, and $\Delta E_{e}$, are changes in $E$, corresponding to change in total sowing area, shift in crop mix, change in $\mathrm{N}$ application rate, and emission intensity, respectively. The change of $\Delta E$ between base and final years is then calculated by the cumulative $\Delta E$ between adjacent years. The sign of the $\Delta E$ indicates a positive or negative effect of the factor on the change of cropland $\mathrm{N}_{2} \mathrm{O}$ emissions between the base and final years, and the potential impacts of nationwide policy interventions related to fertilizer application, crop type and sowing area. 


\section{3. Results}

\subsection{Model performance}

Combining the new $\mathrm{N}$ inputs and irrigation data and the other forcing datasets with the updated SRNM model, we estimated a mean annual $\mathrm{N}_{2} \mathrm{O}$ emission from China's croplands of $0.62 \pm$

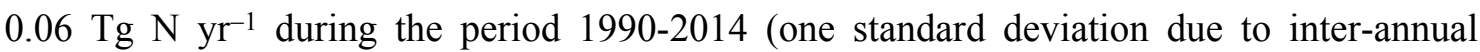
variability of $\mathrm{N}_{2} \mathrm{O}$ emissions), with the spatial distribution shown in Fig. 1a. The validity of our $\mathrm{N}_{2} \mathrm{O}$ emission estimates was supported by internal cross-validation at 345 sites $\left(\mathrm{R}^{2}=0.88\right.$ and 0.90 for upland crops and paddy rice, respectively, Fig. 1b). In addition, our SRNM model outputs performed well in reproducing the spatial contrast and long-term inter-annual variability of $\mathrm{N}_{2} \mathrm{O}$ emissions as well as the sensitivity of $\mathrm{N}_{2} \mathrm{O}$ emission to environmental changes (Figs $\mathrm{S} 1$ and $\mathrm{S} 2$ ). In addition, the $\mathrm{N}_{2} \mathrm{O}$ emissions were corroborated against independent simulations from four process-based models and the estimates from the atmospheric inversion $\left(\mathrm{R}^{2}=0.91\right.$ and 0.66 , respectively, Fig. 1c). This new estimate of China's cropland $\mathrm{N}_{2} \mathrm{O}$ emissions is consistent with the USEPA report $\left(0.59 \mathrm{Tg} \mathrm{N} \mathrm{yr}^{-1}\right.$ ) (USEPA, 2012), and in general fell with the range of process-based models $\left(0.35\right.$ to $0.73 \mathrm{Tg} \mathrm{N} \mathrm{yr}^{-1}$, Fig. 1c). However, it exceeded emission estimates provided by EDGAR v4.3.2 product (JanssensMaenhout et al., 2017) by $43 \%$, the FAOSTAT by $+55 \%$, the GAINS by $67 \%$, and the CNCR for years 1994 and 2005 by $36 \%$ (t-test at the 95\% level, Fig. 1d), but was comparable to the latest CNCR report for the year $2012\left(0.78 \mathrm{Tg} \mathrm{N} \mathrm{yr}^{-1}\right)$. 
(a)
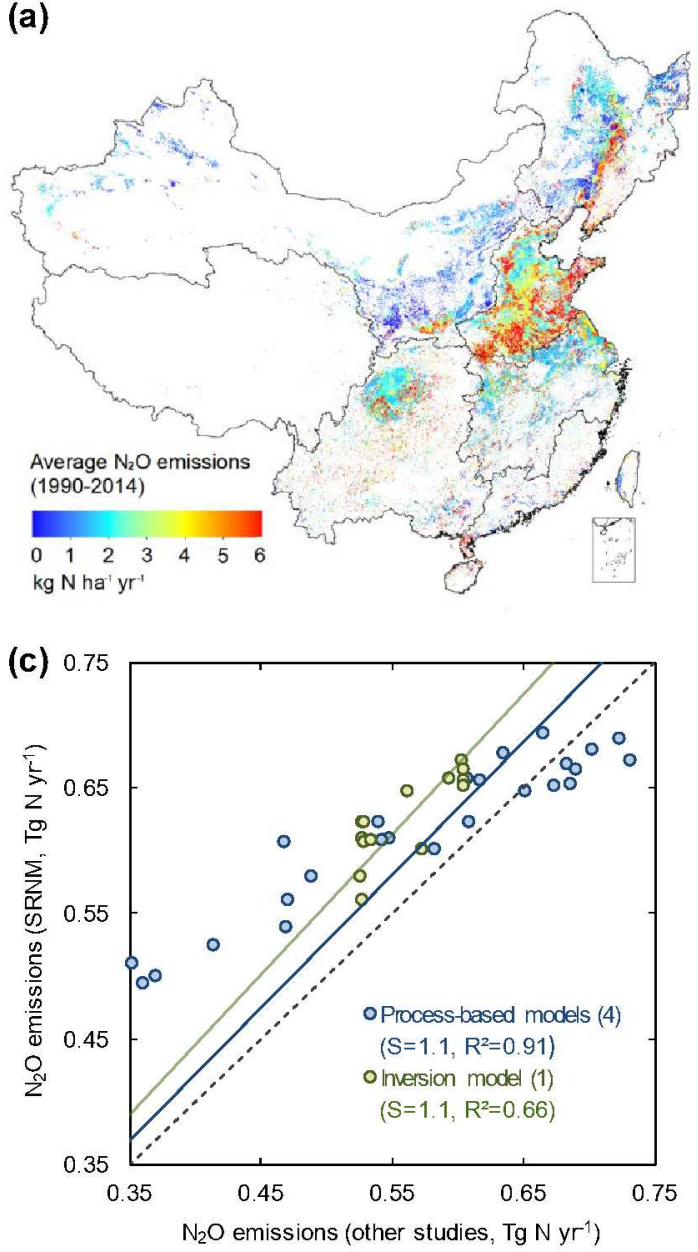

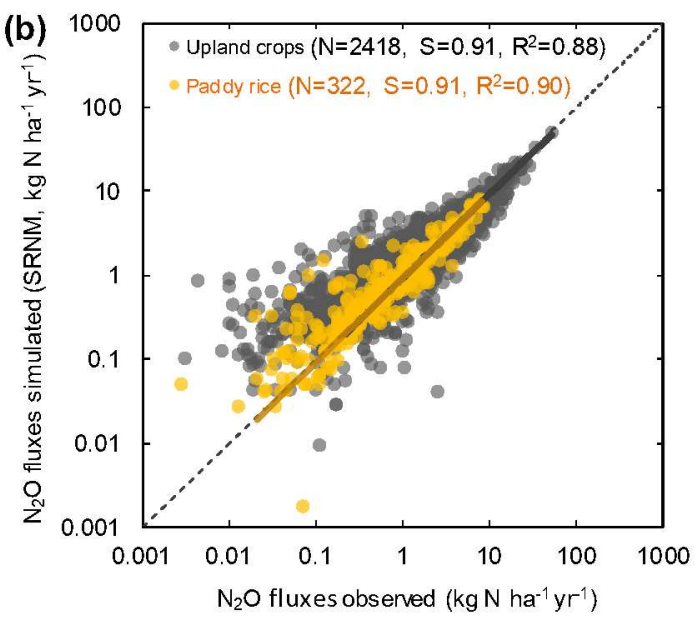

(d)

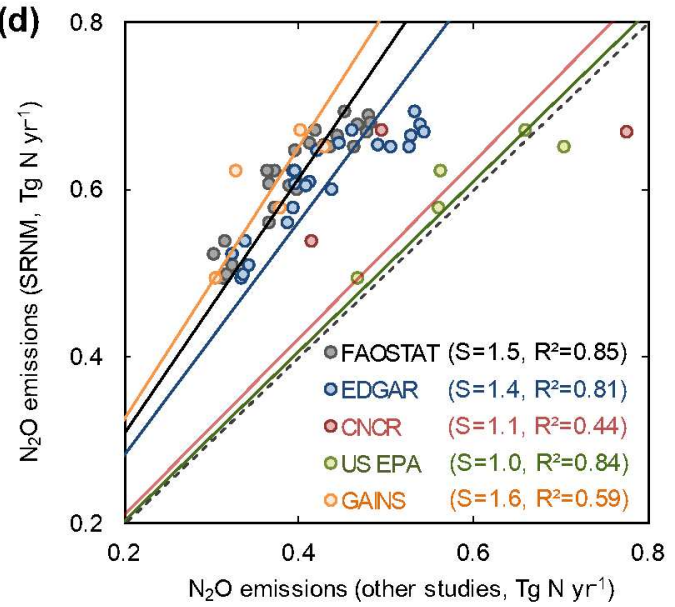

Figure 1. Validation of China's cropland $\mathrm{N}_{2} \mathrm{O}$ emissions from the updated SRNM model. (a) Pattern of mean annual $\mathrm{N}_{2} \mathrm{O}$ emissions simulated (1990-2014). (b) Model performance of the simulated cropland $\mathrm{N}_{2} \mathrm{O}$ fluxes. (c) Comparison of annual cropland $\mathrm{N}_{2} \mathrm{O}$ emissions against the means of process-based models (1990-2014) and inversion models (1996-2008). Each point represents the estimated $\mathrm{N}_{2} \mathrm{O}$ emissions from Chinese croplands for a certain year. Numbers in brackets show the number of models. (d) Comparison of annual cropland $\mathrm{N}_{2} \mathrm{O}$ emissions with the emission inventories, including FAOSTAT (1990-2014), EDGAR v4.3.2 (1990-2012), CNCR (1994, 2005, 2012); USEPA (1990-2005), and GAINS (1990, 1995, 2000, 2005, 2010). Note that $\mathrm{N}, \mathrm{S}$, and $\mathrm{R}^{2}$ denote the number of measurements, slope of regression line, and coefficient of determination, respectively. 

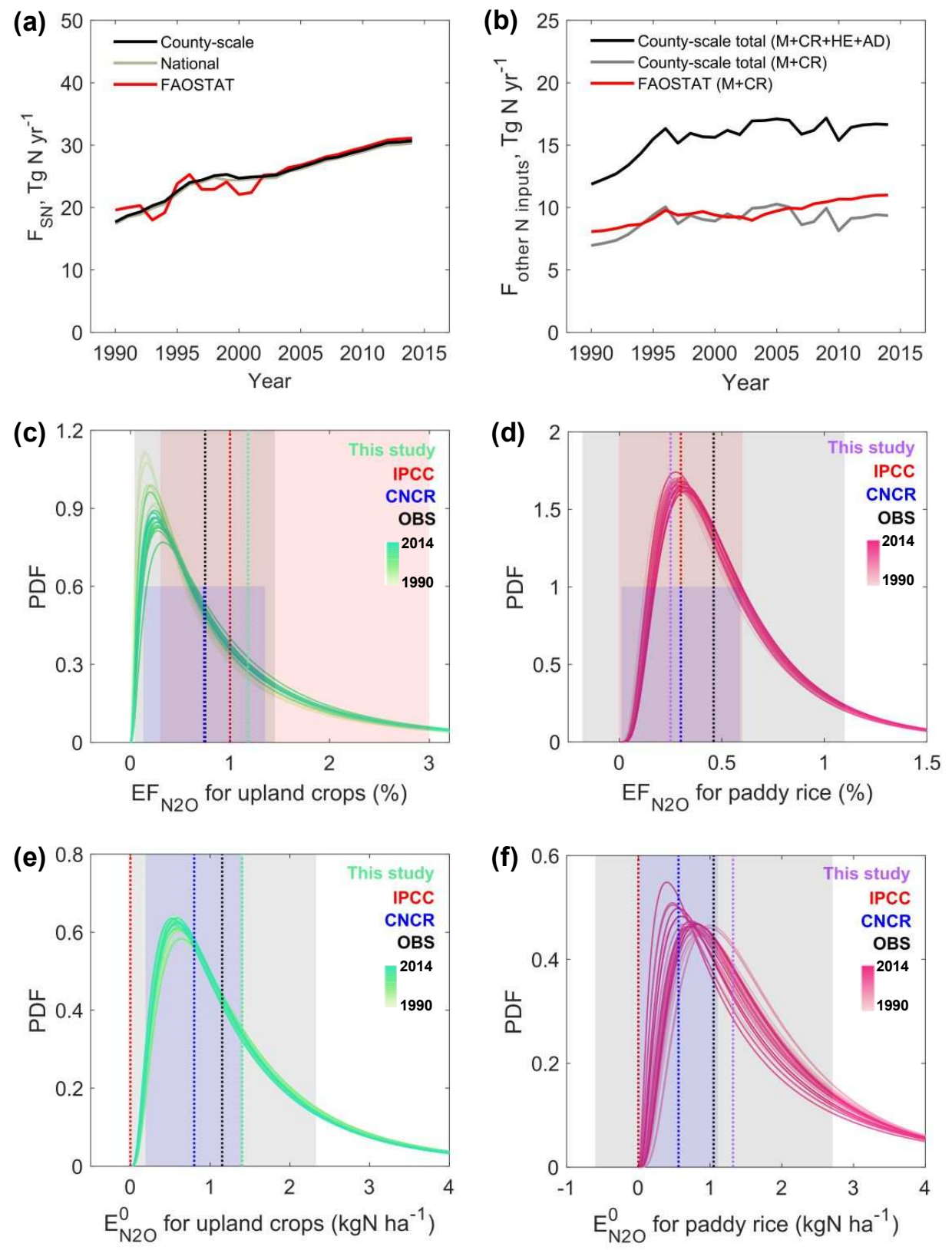

Figure 2. Comparisons of $\mathrm{N}$ inputs, emission factor and 'background' anthropogenic emissions of cropland $\mathbf{N}_{2} \mathbf{O}$ in China. (a) Synthetic fertilizers applied to croplands. (b) Other $\mathrm{N}$ inputs, including manure (M), crop residues (CR), human excreta (HE) returned to croplands, and atmospheric deposition (AD) over croplands. (c) Lognormal probability density function of emission factor for all upland crops based on gridded results during the period 1990-2014, where the dashed lines indicate the median values, and shaded areas represent standard deviation for this study and observed values (OBS) or 95\% confidence interval for the IPCC and the CNCR. (d) Same as panel $\mathbf{c}$ but for paddy rice. (e) Same as panel $\mathbf{c}$ but for background emission $\left(\mathrm{E}^{0}\right)$ of upland rice. (d) Same as panel $\mathbf{c}$ but for $\mathrm{E}^{0}$ of paddy rice. Note that the definition of FAOSTAT, IPCC, CNCR, and OBS can be found in the text. 
322 The differences between our estimates and other inventories were primarily attributed to the updates of $\mathrm{N}$ input data, emission factors, and 'background' anthropogenic emissions from soil residual N (Fig. 2). First, our county-scale estimation of synthetic $\mathrm{N}$ fertilizer application was almost identical to the national statistics and FAOSTAT data (Fig. 2a), whereas the other N inputs were substantially larger because the inclusion of human excretion and atmospheric deposition over croplands (Figs $2 \mathrm{~b}$ and S3). Second, our estimate of the nationally-averaged $\mathrm{N}_{2} \mathrm{O}$ emission factor (EF) for upland crops was larger than IPCC Tier 1 default by $20 \%$ (Fig. 2c), but the EF was $-17 \%$ lower for paddy rice (Fig. $2 d$ and Text S6). Furthermore, the 'background' anthropogenic emissions of $\mathrm{N}_{2} \mathrm{O}(\gamma)$ due to the legacy effect resulting from historical soil $\mathrm{N}$ accumulation were estimated to be $1.40 \pm 0.04 \mathrm{~kg} \mathrm{~N} \mathrm{ha}^{-1} \mathrm{yr}^{-1}$ for upland crops and $1.30 \pm 0.05 \mathrm{~kg} \mathrm{~N} \mathrm{ha}^{-1} \mathrm{yr}^{-1}$ for paddy rice in this study (Figs 2e and 2f), while they were not fully accounted for by the IPCC Tier 1 inventories. Our estimates of this term were larger than the values used in the CNCR $\left(0.80\right.$ and $\left.0.56 \mathrm{~kg} \mathrm{~N} \mathrm{ha}^{-1} \mathrm{yr}^{-1}\right)$, but generally agreed with the in situ observations (OBS) with zero $\mathrm{N}$ input $\left(1.2 \pm 1.2\right.$ and $1.0 \pm 1.7 \mathrm{~kg} \mathrm{~N} \mathrm{ha}^{-1} \mathrm{yr}^{-1}$ based on 168 and 54 sites, respectively).

\subsection{Trend in cropland $\mathrm{N}_{2} \mathrm{O}$ emissions in China}

Over the period 1990-2014, cropland $\mathrm{N}_{2} \mathrm{O}$ emissions showed a persistent and widespread increase (Fig. S4), because of the significant increase in $\mathrm{N}$ inputs to croplands. However, the rate of this increase slowed down from $11.2 \mathrm{Gg} \mathrm{N} \mathrm{yr}^{-2}(P<0.001)$ before 2003 to $2.8 \mathrm{Gg} \mathrm{N}$ $\mathrm{yr}^{-2}(P=0.02)$ afterwards (Figs $3 \mathrm{a}$ and $\left.3 \mathrm{~b}\right)$, a turning point detected by Pettitt's test (Pettitt, 1979) $(P<0.001)$. This slower, insignificant growth of cropland $-\mathrm{N}_{2} \mathrm{O}$ emissions was confirmed by the process-based models with the same forcing datasets (19.8 $\mathrm{Gg} \mathrm{N} \mathrm{yr}^{-2}$ for 1990-2003, $P$ $<0.001 ; 4.8 \mathrm{Gg} \mathrm{N} \mathrm{yr}^{-2}$ for 2003-2014, $P=0.15$; Fig. 3b). We then divided the past 25 years into two periods covering 1990-2003 (P1) and 2003-2014 (P2). Regionally, 

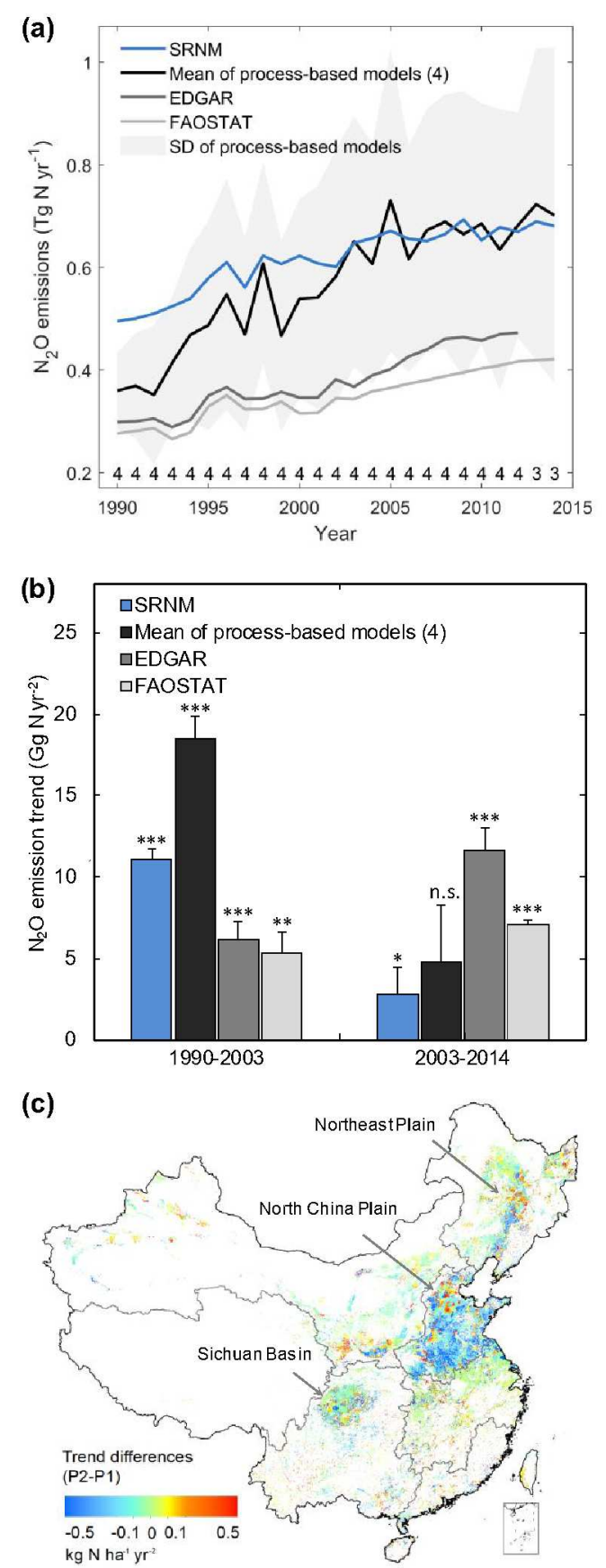

348 Figure 3. The inter-annual variability of cropland- $\mathbf{N}_{2} \mathbf{O}$ emissions in China. (a) Temporal 349 evolution of annual cropland- $\mathrm{N}_{2} \mathrm{O}$ emissions based on the updated SRNM model, an ensemble 350 of four process-based models, and previous inventories (EDGAR v4.3.2 and FAOSTAT). 351 Shaded area indicates the standard deviation of the results from process-based models. 352 Numbers at the bottom show the number of process-based models available for each year. (b) 353 Trends in cropland- $\mathrm{N}_{2} \mathrm{O}$ emissions based on different approaches for two different periods ( $\mathrm{P}$ : 354 1990-2003, P2: 2003-2014); ${ }^{* * *}, * *$, and * indicate significance of the trends at the $99.9 \%, 99 \%$ 355 and $95 \%$ confidence interval, respectively; n.s., not significant. (c) Pattern of the difference in $356 \quad \mathrm{~N}_{2} \mathrm{O}$ trends between the two periods. 
approximately $64 \%$ of the Chinese sowing area experienced a weakened growth or even a decline of $\mathrm{N}_{2} \mathrm{O}$ emissions in $\mathrm{P} 2$, primarily located in major cropping areas such as the North China Plain, the Sichuan Basin, and a part of the Northeast Plain (Fig. 3c), while the rest showed a growth in emissions, mainly in Heilongjiang province and the Northwest China (Fig. 3c). By contrast, the estimates provided by EDGAR v4.3.2 have suggested enhanced growth of cropland $-\mathrm{N}_{2} \mathrm{O}$ emissions across China (Figs $3 \mathrm{~b}$ and S5). The estimated growth rate of cropland- $\mathrm{N}_{2} \mathrm{O}$ emissions in EDGAR v4.3.2 after $2003\left(11.6 \mathrm{Gg} \mathrm{N} \mathrm{yr}^{-2}, P<0.001\right)$ is much larger than that for 1990-2003 (6.2 $\mathrm{Gg} \mathrm{N} \mathrm{yr}^{-2}, P<0.001$; Fig. 3b). Differences in emission trends between our estimates and the EDGAR product are mainly focused around the North China Plain (Fig. S5).

\subsection{Drivers of China's cropland- $\mathrm{N}_{2} \mathrm{O}$ emission trends}

The decomposition analysis in Fig. 4 shows the contribution of each of the four drivers to the change in cropland $-\mathrm{N}_{2} \mathrm{O}$ emissions in China and its seven major cropping regions. For $\mathrm{P} 1$, the trend of emissions was associated with a growth of $\mathrm{N}_{\text {rate }}$ for all crops (Fig. 4a), mainly located in the North China Plain and the Northeast Plain (Figs 4c-4d). For P2, the slower growth in cropland $-\mathrm{N}_{2} \mathrm{O}$ emissions across China was driven by the downward influences from the reduced $\mathrm{N}_{\text {rate }}$ and emission intensities, which largely offset the strong expansion of sowing areas particularly in the Northeast Plain (Figs 4a and 4c). By contrast, the shifts in the crop mix and in emission intensity contributed marginally to changes in emissions in both periods (Fig. $4 a)$.

Contributions of the four driving factors to cropland $-\mathrm{N}_{2} \mathrm{O}$ emission trends differed between cropping regions (Figs $4 \mathrm{~b}-4 \mathrm{~h}$ ). During the period $\mathrm{P} 1$, the trend in cropland $-\mathrm{N}_{2} \mathrm{O}$ emissions was explained by the growth of $\mathrm{N}_{\text {rate }}$ in most of the major cropping regions, except for the Northwest 
where there was deceased emission intensity. During the period P2, sowing area expansion became the largest contributor to the positive cropland $-\mathrm{N}_{2} \mathrm{O}$ emission trends in the Northeast Plain, the Northwest, the Southwest, as well as the lower reaches of the Yangtze River basin. However, the decrease in emission intensity dominated the change in cropland $-\mathrm{N}_{2} \mathrm{O}$ emissions in the North China Plain, and $\mathrm{N}_{\text {rate }}$ contributed to the changes in the Southeast and QinghaiTibet Plateau.
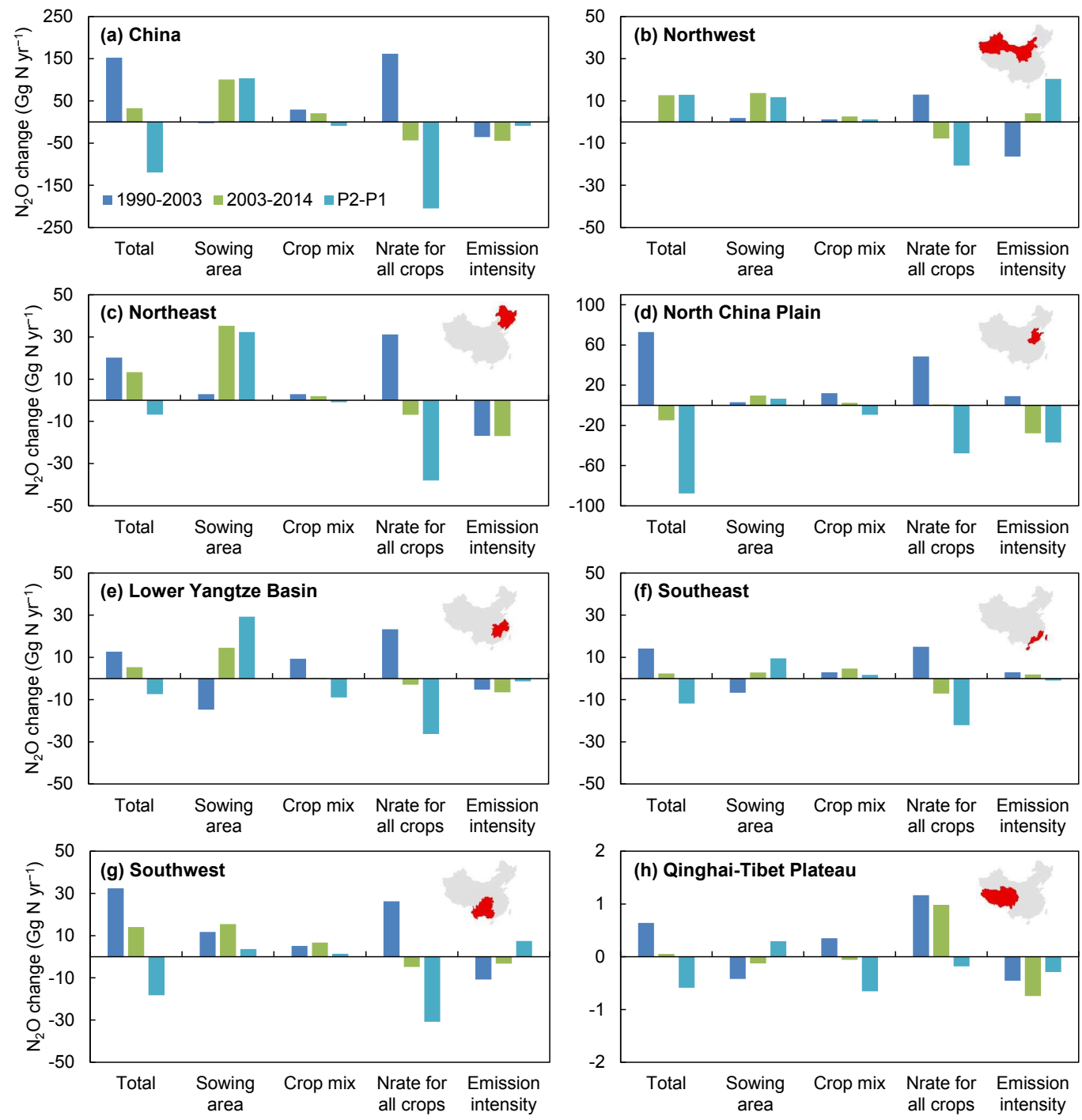

Figure 4. Contribution of different drivers to the change in cropland- $\mathrm{N}_{2} \mathrm{O}$ emissions by cropping region during 1990-2003 (P1) and 2003-2014 (P2). a. China; b. northwest China; c. northeast China; d. North China Plain; e. lower Yangtze Basin; f. southeast China; g. southwest China; h. Qinghai-Tibet Plateau. Note varying vertical-axes. The length of each bar reflects the contribution of each factor during the corresponding period. 

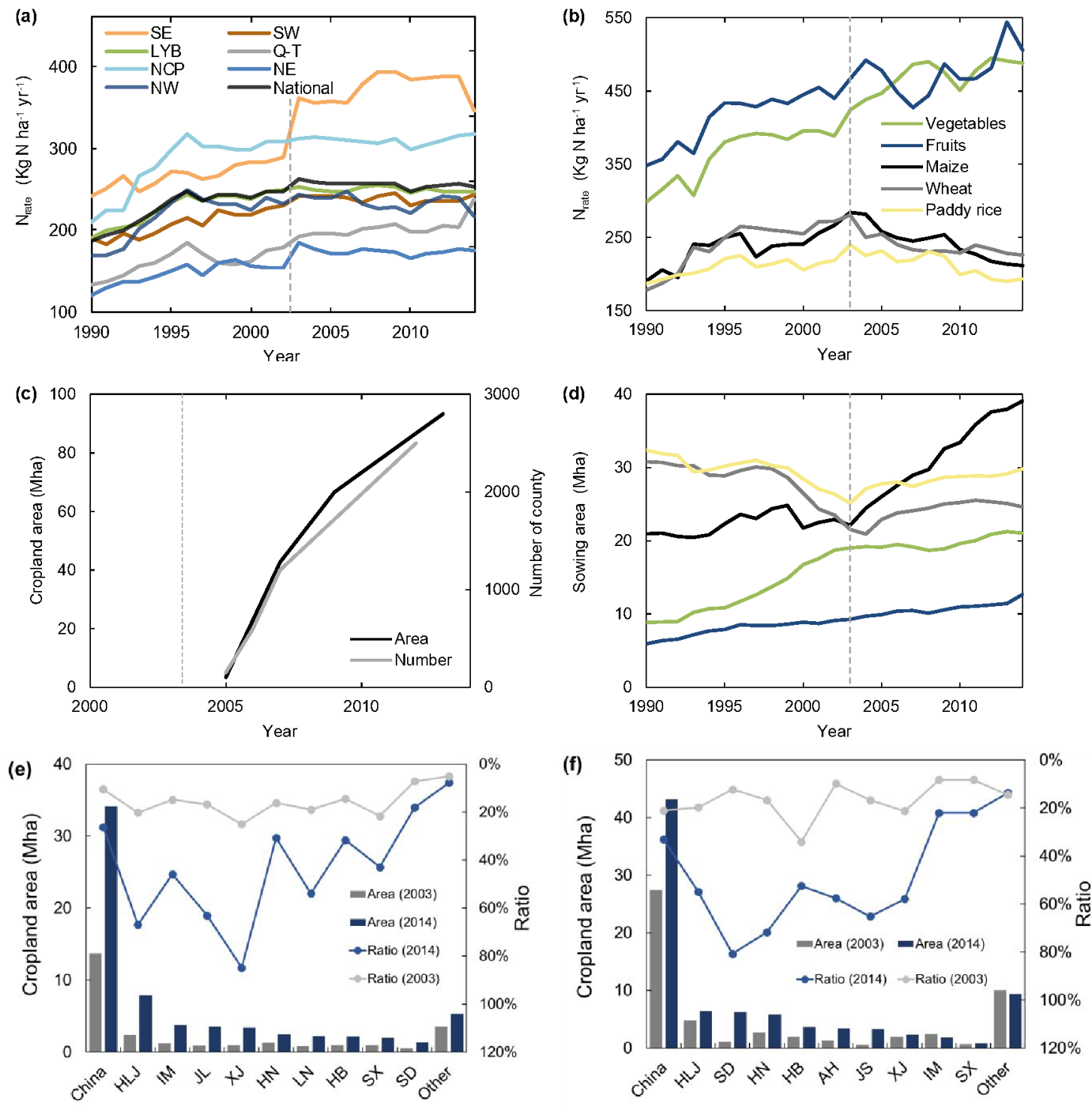

Figure 5. Temporal evolution of agricultural management in China. a. $N_{\text {rate }}$ in 7 major cropping regions. b. $\mathrm{N}_{\text {rate }}$ by crops. c. National sowing areas and county number applied by the Nationwide Soil Testing and Formulation Fertilization Program. d. National sowing areas by crops. e. Provincial areas and ratio of croplands using mechanically-aided deep placement of fertilizers in 2003 and 2014, where the ratio is calculated as the croplands using this technology divided by national cropland area. f. Same as panel e but for crop residues returned to croplands. The seven cropping regions include Southeast (SE), Southwest (SW), Lower Yangtze Basin (LYB), Qinghai-Tibet Plateau (Q-T), North China Plain (NCP), Northeast (NE) and Northwest (NW). HLJ: Heilongjiang, IM: Inner Mongolia, JL: Jilin, XJ: Xinjiang, HN: Henan, LN: Liaoning, HB: Hebei, SX: Shanxi, SD: Shandong, AH: Anhui, JS: Jiangsu

Overall, in period P2 (after 2003), the reduction of $\mathrm{N}_{\text {rate }}$ dominated the slowdown of cropland$\mathrm{N}_{2} \mathrm{O}$ emissions in China. According to nationwide statistics, China's $\mathrm{N}_{\text {rate }}$ showed a clear 
reversal in trend around 2003, from an increasing rate of $+5.1 \mathrm{~kg} \mathrm{~N} \mathrm{ha}^{-1} \mathrm{yr}^{-2}$ in $\mathrm{P} 1$ to a decrease of $-0.7 \mathrm{~kg} \mathrm{~N} \mathrm{ha}^{-1} \mathrm{yr}^{-2}$ in $\mathrm{P} 2$, although it varied across different cropping regions (Fig. 5a). Similar decreases in crop-specific $\mathrm{N}_{\text {rate }}$ were found for wheat, maize, and paddy rice, but not for vegetables and fruits, all with Pettitt's test (Fig. 5b, $\mathrm{p}<0.001$ ). Interestingly, these change points were, in general, coincident with changes in cropland- $\mathrm{N}_{2} \mathrm{O}$ emissions in China. The reductions of $\mathrm{N}_{\text {rate }}$ were mainly due to declines in synthetic fertilizer uses, particularly in the eastern and central China, the Yunnan-Guizhou Plateau, and the North China Plain (Fig. S6).

\section{Discussion}

Reliable estimation of cropland $-\mathrm{N}_{2} \mathrm{O}$ emissions and their drivers is fundamental to the development of policy for sustainable N management. Previous estimates have shown large differences in the magnitude and temporal evolution of annual cropland $-\mathrm{N}_{2} \mathrm{O}$ emissions. This has mainly been due to the lack of high-resolution data on agricultural management and of spatial representation in the models. Our updated SRNM model, along with new, crop-specific gridded datasets of $\mathrm{N}$ inputs and irrigation, permits a new insight into the spatial contrast and inter-annual variability of cropland $-\mathrm{N}_{2} \mathrm{O}$ emissions, and associates these with policy-driven technological adoption and environmental changes.

The reduced $\mathrm{N}_{\text {rate }}$ suggests that national $\mathrm{N}$ use efficiency of fertilizers has improved over recent decades, given that there was no reduction in per-area crop yields according to the national statistics (Sun \& Huang, 2012). One of the most effective methods of making fertilizer use more efficient is to match the supply of nutrients with demand during field application (Richards et al., 2015). Such an approach was one of targets of the Nationwide Soil Testing and Formulation Fertilization Program, launched in the early 2000s (Table S7). This program started with staple crops, which account for $\sim 50 \%$ of national $\mathrm{N}$ inputs on average, but after 
4332010 it extended to a number of cash crops. These improved $\mathrm{N}$ use efficiencies for staple crops 434 were also found in the most recent study (Zou et al., 2018). According to national statistics 435 (Sun \& Huang, 2012), such technologies increased in prevalence on croplands from 3.3 million ha in 200 counties, to $\sim 93$ million ha in 2,498 counties (Fig. 5c). In addition, spatial reallocation of crops has extensively happened in China over recent decades, and is characterized by an emerging shift from peri-urban areas in the South and Central China (high $\mathrm{N}$ rate) to rural areas in the North (low $\mathrm{N}$ rate) because of urbanization (Fig. S7; Zou et al., 2018). Although the effectiveness of the Nationwide Soil Testing and Formulation Fertilization Program on the $\mathrm{N}_{\text {rate }}$ is difficult to quantify at the regional scale, these measures contributed to the decline in $\mathrm{N}_{\text {rate }}$ across China (Chen et al., 2014).

The increased sowing area was identified as the second important driver of cropland $-\mathrm{N}_{2} \mathrm{O}$ emission trends in P2 that partially offset the effect of decreasing $\mathrm{N}_{\text {rate. }}$ The shift in crop mix resulted in positive emission trends in $\mathrm{P} 1$, but made negligible contributions across most cropping regions in P2. Specifically, sowing areas by crop have changed in line with multiple nationwide crop structural transition programs in China. During the period 1990-2003, the Government of China encouraged the growth of cash crops to meet increased consumption requirements. According to national statistics, the sowing areas of vegetables and fruits increased by $115 \%$ and $57 \%$ in the P1 (Fig. 5d), respectively. Meanwhile, the areas sown to wheat and paddy rice declined by $-30 \%$ and $-22 \%$, and sowing area of maize remained at the level as that in 1990. This structural transition in cropping patterns that occurred in P1 resulted in more cropland $-\mathrm{N}_{2} \mathrm{O}$ emissions, because vegetables and fruits, which constitute the major area of cash crops, have an emission factor two times higher than that of staple crops (Dobbie \& Smith, 2003). During P2 (after 2003), the Government of China aimed to stabilize the production of cash crops, but to also restore the production of cereal crops. As a result, the 
sowing areas of staple crops increased by $36 \%$, while the sowing areas of vegetables, fruits, and oil crops were increased by only $11 \%$ (Fig. $5 \mathrm{~d}$ ). Compared to the period P1, this shift in crop mix in P2 exerted a lower upward pressure on cropland $-\mathrm{N}_{2} \mathrm{O}$ emissions, particularly in the major cropping regions. The results underscore the significance of land-use changes to the spatial and inter-annual variabilities of $\mathrm{N}_{2} \mathrm{O}$ emissions.

Our results show that emission intensity decreased during both periods and had a negative effect on the growth of cropland- $\mathrm{N}_{2} \mathrm{O}$ emissions across most of the cropping regions. Scenario simulations based on the SRNM (see Text S7) suggest that $\mathrm{N}_{\text {rate }}$ was the dominant factor controlling the emission intensity trend, followed by soil organic carbon (SOC) and water inputs (Fig. S8). Increased SOC offset $19 \%$ and $51 \%$ of the negative effects from $\mathrm{N}_{\text {rate }}$ for P1 and $\mathrm{P} 2$, respectively. Thus whilst $\mathrm{C}$ sequestration can help offset some of the cropland emissions of $\mathrm{CO}_{2}$, a recent study suggests that carbon emission equivalents of non- $\mathrm{CO}_{2} \mathrm{GHG}$ emissions are currently $\sim 12$ times greater than carbon uptake by Chinese croplands over 100year time horizon (B. Gao et al., 2018). SOC also played a role in increasing $\mathrm{N}_{2} \mathrm{O}$ emissions with a positive correlation between $\mathrm{N}_{2} \mathrm{O}$ emissions and SOC reported in field (Figueiredo, Enrich - Prast, \& Rütting, 2016), laboratory studies (Jäger, Stange, Ludwig, \& Flessa, 2011), meta-analyses (Bouwman, Boumans, \& Batjes, 2002; Charles et al., 2017), and data mining analysis (Perlman et al., 2014). The postive effect of SOC could be explained by high SOC providing sources of energy, $\mathrm{C}$ and $\mathrm{N}$ for nitrifying and denitrifying microorganisms, and creating anaerobic conditions favoring the oxidation-reduction reaction for denitrification (Charles et al., 2017).

At present, the attribution of trends in cropland $-\mathrm{N}_{2} \mathrm{O}$ emissions to driving factors contains some uncertainties. Other potential factors responsible for the decline in emissions seem also to be 
important, but were difficult to consider explicitly. These include, among others, changes in crop cultivars (Zhang, Fan, Wang, \& Shen, 2009), cultivation technology improvements places (Jiang et al., 2018), timing (Jiang et al., 2018; Wang et al., 2016) and placement methods (Chen, Wang, Liu, Lu, \& Zhou, 2016), and changes in fertilizer type (Bouwman et al., 2002). For example, multiple field trials for staple crops in China suggest a significant increase in N-use efficiency (ratio of yield to $\mathrm{N}_{\text {rate }}$ ) associated with cultivar improvement over recent decades (de Dorlodot et al., 2007). However, this does not mean a coincident reduction of $\mathrm{N}_{\text {rate }}$ because crop yields (i.e., per-area crop production of these new cultivars) grew synergistically, and thus might require more fertilizer per unit of cropped area. The improvement of cultivation technology plays an important role in influencing cropland $-\mathrm{N}_{2} \mathrm{O}$ emissions. For example, the proportion of croplands using mechanically-aided deep placement of fertilizers increased from $11 \%$ in 2003 to $26 \%$ at present, particularly in the north of China (Fig. 5e), decreasing the N losses and thereby cropland $-\mathrm{N}_{2} \mathrm{O}$ emissions. Increasing the return of crop residues, also particularly in the North China Plain, has been hypothesized as an emerging driver for the change of $\mathrm{N}_{\text {rate. }}$ In these regions, crop residues returned to croplands accounted for from $21 \%$ in 2003 to $33 \%$ of croplands in 2014 (Fig. 5f), increasing the potential to replace the application of synthetic fertilizers, and to change carbon and $\mathrm{N}$ biogeochemical cycles in soils (Chen, $\mathrm{Li}$, $\mathrm{Hu}$, \& Shi, 2013; Xia et al., 2018). However, the effect of crop residues on cropland- $\mathrm{N}_{2} \mathrm{O}$ emissions is more complex and modified by the prevalence of aerobic and anaerobic soil conditions (Xia et al., 2018), and also the chemical composition of the plant material (S. Gao et al., 2018).

In summary, the results from this study underline the advantage of high-resolution agricultural activity data and emission intensity detailed by crop type, land-use dynamics and technology improvement to understand the change in cropland $-\mathrm{N}_{2} \mathrm{O}$ emissions. Most of the state-of-the-art 
emission inventories that aim to quantify global $\mathrm{N}_{2} \mathrm{O}$ emissions, fail to capture either the magnitude or temporal trends in China. This is because firstly, an IPCC default EF of $1 \%$ assumes a constant relationship between $\mathrm{N}$ input and $\mathrm{N}_{2} \mathrm{O}$ emissions. This cannot reproduce the spatial and temporal responses of $\mathrm{N}_{2} \mathrm{O}$ emission to environmental changes. Secondly, emission inventories, in general, disaggregate national-scale or low-resolution fertilizer and irrigation data into gridded maps to generate cropland- $\mathrm{N}_{2} \mathrm{O}$ emission patterns. This would be likely to lower emission estimates from regions predominantly fertilized at high $\mathrm{N}$ inputs (e.g., the North China Plain), while increasing emission estimates from under-fertilized areas (e.g., the Northeast Plain). Process-based terrestrial biosphere models (TBM) still face many challenges in modelling changes in cropland- $\mathrm{N}_{2} \mathrm{O}$ emissions (Sandor et al. 2018). Though most of them consider the biotic and abiotic processes involved $\mathrm{N}_{2} \mathrm{O}$ production, they also generate divergent estimates of cropland- $\mathrm{N}_{2} \mathrm{O}$ emissions and spatio-temporal patterns (Tian et al., 2018). Possible reasons for divergent estimates among TBMs are the incomplete model representation of $\mathrm{N}_{2} \mathrm{O}$ emissions in response to agricultural management practices and uniform response functions of the $\mathrm{N}_{2} \mathrm{O}$ flux to environmental conditions (e.g., SOC). Improving the representation of crop-specific agricultural activity data and the regional adoptions of $\mathrm{N}_{2} \mathrm{O}$ flux response are recommended for future projections.

The updated SRNM model for China's cropland- $\mathrm{N}_{2} \mathrm{O}$ emissions could be extended to other countries for updating their cumulative emissions and their contributions to global historical radiative forcing and ozone depletion. The decomposition of cropland- $\mathrm{N}_{2} \mathrm{O}$ emission trends to underlying drivers could facilitate the tracking of key indicators that require significant change. Our modeling results also highlight that technological adoption was intertwined with policy interventions in China. We argue that designing more realistic future scenarios for technological adoption will increase the likelihood that policies will be implemented to set 
targets and incentives for cropland- $\mathrm{N}_{2} \mathrm{O}$ emission mitigation.

\section{ACKNOWLEDGMENT}

This study was supported by the National Natural Science Foundation of China (41671464; 7181101181), the National Key Research and Development Program of China (2016YFD0800501; 2018YFC0213304), 111 Project (B14001), the GCP-INI Global $\mathrm{N}_{2} \mathrm{O}$

Budget and the INMS Asia Demo Activities. The input of P.S. contributes to the UK-China Virtual Joint Centre on Nitrogen "N-Circle" funded by the Newton Fund via UK BBSRC/NERC (BB/N013484/1). We acknowledged Eric Ceschia, Kristiina Regina, Dario Papale, and the NANORP for sharing a part of observation data.

\section{REFERENCES}

Alexandratos, N., \& Bruinsma, J. (2012). World agriculture towards 2015/2030: The 2012 Revision. ESA Working Paper (Vol. 12, No. 3). FAO, Roma. https://doi.org/10.1016/S0264-8377(03)00047-4

Allen, M. R., Coninck, H. D., Connors, S., Engelbrecht, F., Ferrat, M., Ford, J., ... Taylor, M. IPCC Special Report on Global Warming of $1.5^{\circ} \mathrm{C}$. In Press.

Ang, B. W. (2015). LMDI decomposition approach: A guide for implementation. Energy Policy, 86, 233-238. https://doi.org/10.1016/j.enpol.2015.07.007

Bouwman, A. F., Boumans, L. J. M., \& Batjes, N. H. (2002). Emissions of $\mathrm{N}_{2} \mathrm{O}$ and NO from fertilized fields: Summary of available measurement data. Global Biogeochemical Cycles, 16(4), 6-1-6-13. https://doi.org/10.1029/2001GB001811

Carlson, K. M., Gerber, J. S., Mueller, N. D., Herrero, M., MacDonald, G. K., Brauman, K. A., ... West, P. C. (2017). Greenhouse gas emissions intensity of global croplands. Nature 
Climate Change, 7(1), 63-68. https://doi.org/10.1038/nclimate3158

Charles, A., Rochette, P., Whalen, J. K., Angers, D. A., Chantigny, M. H., \& Bertrand, N. (2017). Global nitrous oxide emission factors from agricultural soils after addition of organic amendments: A meta-analysis. Agriculture, Ecosystems and Environment, 236, 88-98. https://doi.org/10.1016/j.agee.2016.11.021

Chen, H., Li, X., Hu, F., \& Shi, W. (2013). Soil nitrous oxide emissions following crop residue addition: A meta-analysis. Global Change Biology, 19(10), 2956-2964. https://doi.org/10.1111/gcb.12274

Chen, M., Chen, J., \& Sun, F. (2010). Estimating nutrient releases from agriculture in China: An extended substance flow analysis framework and a modeling tool. Science of the Total Environment, 408(21), 5123-5136. https://doi.org/10.1016/j.scitotenv.2010.07.030

Chen, X., Cui, Z., Fan, M., Vitousek, P., Zhao, M., Ma, W., ... Zhang, F. (2014). Producing more grain with lower environmental costs. Nature, 514(7523), 486-489. https://doi.org/10.1038/nature13609

Chen, Z., Wang, H., Liu, X., Lu, D., \& Zhou, J. (2016). The fates of ${ }^{15} \mathrm{~N}$-labeled fertilizer in a wheat-soil system as influenced by fertilization practice in a loamy soil. Scientific Reports, 6, 34754. Retrieved from https://doi.org/10.1038/srep34754

China Renewable Energy Engineering Insitute. (2014). Evaluation of China's water resources and its exploitation and utilization. Beijing: China Water \& Power Press.

National Development and Reform Commission (NDRC) (2017). The People's Republic of China first biennial update report on climate change. Retrieved from http://qhs.ndrc.gov.cn/dtjj/201701/W020170123346264208002.pdf

de Dorlodot, S., Forster, B., Pagès, L., Price, A., Tuberosa, R., \& Draye, X. (2007). Root system architecture: opportunities and constraints for genetic improvement of crops. Trends in Plant Science, 12(10), 474-481. https://doi.org/10.1016/j.tplants.2007.08.012 
Del Grosso, S. J., Ojima, D. S., Parton, W. J., Stehfest, E., Heistemann, M., DeAngelo, B., \& Rose, S. (2009). Global scale DAYCENT model analysis of greenhouse gas emissions and mitigation strategies for cropped soils. Global and Planetary Change, 67, 44-50. https://doi.org/10.1016/j.gloplacha.2008.12.006

Dobbie, K. E. , \& Smith, K. A. (2003). Nitrous oxide emission factors for agricultural soils in Great Britain: the impact of soil water-filled pore space and other controlling variables. Global Change Biology, 9(2), 204-218. https://doi.org/10.1046/j.1365-2486. 2003.00563.x

Ehrhardt, F., Soussana, J. F., Bellocchi, G., Grace, P., McAuliffe, R., Recous, S., ... \& Basso, B. (2018). Assessing uncertainties in crop and pasture ensemble model simulations of productivity and $\mathrm{N}_{2} \mathrm{O}$ emissions. Global Change Biology, 24(2), 603-616. https://doi.org/10.1111/gcb.13965

Figueiredo, V., Enrich - Prast, A., \& Rütting, T. (2016). Soil organic matter content controls gross nitrogen dynamics and $\mathrm{N}_{2} \mathrm{O}$ production in riparian and upland boreal soil. European Journal of Soil Science, 67(6), 782-791. https://doi.org/10.1111/ejss.12384

Flörke, M., Schneider, C., \& McDonald, R. I. (2018). Water competition between cities and agriculture driven by climate change and urban growth. Nature Sustainability, 1, 51-58. https://doi.org/10.1038/s41893-017-0006-8

Food and Agricultural Organization of the United nations (FAO). FAOSTAT data. Retrieved June 18, 2018, from http://www.fao.org/faostat/en/\#data

Gao, B., Huang, T., Ju, X., Gu, B., Huang, W., Xu, L., ... Cui, S. (2018). Chinese cropping systems are a net source of greenhouse gases despite soil carbon sequestration. Global Change Biology, 24(12), 5590-5606. https://doi.org/10.1111/gcb.14425

Gao, S., Chang, D., Zou, C., Cao, W., Gao, J., Huang, J., ... Thorup-Kristensen, K. (2018). Archaea are the predominant and responsive ammonia oxidizing prokaryotes in a red paddy soil receiving green manures. European Journal of Soil Biology, 88, 27-35. 
https://doi.org/https://doi.org/10.1016/j.ejsobi.2018.05.008

Gerber, J. S., Carlson, K. M., Makowski, D., Mueller, N. D., Garcia de Corstazar-Atauri, I., Havlík, P., ... West, P. C. (2016). Spatially explicit estimates of $\mathrm{N}_{2} \mathrm{O}$ emissions from croplands suggest climate mitigation opportunities from improved fertilizer management. Global Change Biology, 22(10), 3383-3394. https://doi.org/10.1111/gcb.13341

Guan, D., Meng, J., Reiner, D. M., Zhang, N., Shan, Y., Mi, Z., ... Davis, S. J. (2018). Structural decline in China's $\mathrm{CO}_{2}$ emissions through transitions in industry and energy systems. Nature Geoscience, 11(8), 551-555. https://doi.org/10.1038/s41561-018-01611

International Fertilizer Association (IFA). IFA database. Retrieved June 18, 2018, from http://ifadata.fertilizer.org/ucSearch.aspx

IPCC. (2006). Guidelines for National Greenhouse Gas Inventories. https://doi.org/http://www.ipccnggip.iges.or.jp/public/2006g1/pdf/2_Volume2/V2_3_Ch3_Mobile_Combustion.pdf

Ito, A., \& Inatomi, M. (2012). Use of a process-based model for assessing the methane budgets of global terrestrial ecosystems and evaluation of uncertainty. Biogeosciences, 9(2), 759773. https://doi.org/10.5194/bg-9-759-2012

Jäger, N., Stange, C. F., Ludwig, B., \& Flessa, H. (2011). Emission rates of $\mathrm{N}_{2} \mathrm{O}$ and $\mathrm{CO}_{2}$ from soils with different organic matter content from three long-term fertilization experiments - a laboratory study. Biology and Fertility of Soils, 47(5), 483. https://doi.org/10.1007/s00374-011-0553-5

Janssens-Maenhout, G., Crippa, M., Guizzardi, D., Muntean, M., Schaaf, E., Dentener, F., ... Petrescu, A. M. R. (2017). EDGAR v4.3.2 Global Atlas of the three major Greenhouse Gas Emissions for the period 1970-2012. Earth System Science Data Discussions. https://doi.org/10.5194/essd-2017-79 
Jiang, C., Lu, D., Zu, C., Shen, J., Wang, S., Guo, Z., ... Wang, H. (2018). One-time root-zone $\mathrm{N}$ fertilization increases maize yield, NUE and reduces soil $\mathrm{N}$ losses in lime concretion black soil. Scientific Reports, 8(1), 10258. https://doi.org/10.1038/s41598-018-28642-0

Li, C., Zhuang, Y., Cao, M., Crill, P., Dai, Z., Frolking, S., ... \& Wang, X. (2001). Comparing a process-based agro-ecosystem model to the IPCC methodology for developing a national inventory of $\mathrm{N}_{2} \mathrm{O}$ emissions from arable lands in China. Nutrient Cycling in Agroecosystems, 60(1-3), 159-175. https://doi.org/10.1023/A:101264220

Liu, J., Kuang, W., Zhang, Z., Xu, X., Qin, Y., Ning, J., ... Chi, W. (2014). Spatiotemporal characteristics, patterns and causes of land use changes in China since the late 1980s. Acta Geographica Sinica, 69(1), 3-14. https://doi.org/10.11821/dlxb201401001

Lu, C., \& Tian, H. (2017). Global nitrogen and phosphorus fertilizer use for agriculture production in the past half century: Shifted hot spots and nutrient imbalance. Earth System Science Data, 9(1), 181-192. https://doi.org/10.5194/essd-9-181-2017

Ma, L., Shan, J., \& Yan, X. (2015). Nitrite behavior accounts for the nitrous oxide peaks following fertilization in a fluvo-aquic soil. Biology and Fertility of Soils, 51(5), 563-572. https://doi.org/10.1007/s00374-015-1001-8

Ministry of Agriculture of the People's Republic of China. Regional Planning of Advantageous Agricultural Products (2003-2007). Retrieved March 18, 2018, from http://www.moa.gov.cn/ztzl/ysncpqybjgh/200302/t20030212_54322.htm

Myhre, G., Shindell, D., Breon, F.-M., Collins, W., Fuglestvedt, J., Huang, J., ... Zhang, H. (2013). Anthropogenic and Natural Radiative Forcing. In: Stocker, T. F., D. Qin, G.-K. Plattner, M. Tignor, S. K. Allen, J. Boschung, A. Nauels, Y. Xia, V. Bex \& P. M. Midgley (eds.), Climate Change 2013: The Physical Science Basis. Contribution of Working Group I to the Fifth Assessment Report of the Intergovernmental Panel on Climate Change. Cambridge University Press, Cambridge, United Kingdom and New York, NY, USA, 
1535 pp, doi:10.1017/CBO9781107415324.

National Development and Reform Commission (NDRC). China's National Climate Change Program. Retrieved March 18, 2018, from http://www.chinaun.org/eng/gyzg/t626117.htm

Paustian, K., Lehmann, J., Ogle, S., Reay, D., Robertson, G. P., \& Smith, P. (2016). Climatesmart soils. Nature, 532(7597), 49-57. https://doi.org/10.1038/nature17174

Perlman, J., Hijmans, R. J., \& Horwath, W. R. (2014). A metamodelling approach to estimate global $\mathrm{N}_{2} \mathrm{O}$ emissions from agricultural soils. Global Ecology and Biogeography, 23(8), 912-924. https://doi.org/10.1111/geb.12166

Pettitt, A. N. (1979). A Non-Parametric Approach to the Change-Point Problem. Applied Statistics, 28(2), 126-135. https://doi.org/10.2307/2346729

Philibert, A., Loyce, C., \& Makowski, D. (2012). Quantifying Uncertainties in $\mathrm{N}_{2} \mathrm{O}$ Emission Due to $\mathrm{N}$ Fertilizer Application in Cultivated Areas. PLoS ONE, 7(11), e50950. https://doi.org/10.1371/journal.pone.0050950

Ravishankara, A. R., Daniel, J. S., \& Portmann, R. W. (2009). Nitrous oxide $\left(\mathrm{N}_{2} \mathrm{O}\right)$ : The dominant ozone-depleting substance emitted in the 21st century. Science, 326(5949), 123-125. https://doi.org/10.1126/science.1176985

Richards, M., Butterbach-Bahl, K., Jat, M. L., Ortiz-Monasterio, I., Sapkota, T., \& Lipinski, B. (2015). Site-Specific Nutrient Management: Implementation guidance for policymakers and investors. https://doi.org/10.1177/002204269702700108

Saikawa, E., Prinn, R. G., Dlugokencky, E., Ishijima, K., Dutton, G. S., Hall, B. D., ... Elkins, J. W. (2014). Global and regional emissions estimates for $\mathrm{N}_{2} \mathrm{O}$. Atmospheric Chemistry and Physics, 14(9), 4617-4641. https://doi.org/10.5194/acp-14-4617-2014

Sandor, R., Ehrhardt, F., Brilli, L., Carozzi, M., Recous, S., Smith, P., ... Bellocchi, G. (2018). The use of biogeochemical models to evaluate mitigation of greenhouse gas emissions 
682

683

684

685

686

687

from managed grasslands. Science of the Total Environment, 642, 292-306. https://doi.org/10.1016/j.scitotenv.2018.06.020

Shcherbak, I., Millar, N., \& Robertson, G. P. (2014). Global metaanalysis of the nonlinear response of soil nitrous oxide $\left(\mathrm{N}_{2} \mathrm{O}\right)$ emissions to fertilizer nitrogen. Proceedings of the National Academy of Sciences, 111(25), 9199-9204. https://doi.org/10.1073/pnas.1322434111

Song, X., Liu, M., Ju, X., Gao, B., Su, F., Chen, X. \& Rees, R. M. (2018). Nitrous oxide emissions increase exponentially when optimum nitrogen fertilizer rates are exceeded in the North China Plain. Environmental Science \& Technology, 52(21), 12504-12513. https://doi.org/10.1021/acs.est.8b03931

Sun, W., \& Huang, Y. (2012). Synthetic fertilizer management for China's cereal crops has reduced $\mathrm{N}_{2} \mathrm{O}$ emissions since the early 2000s. Environmental Pollution, 160, 24-27. https://doi.org/10.1016/j.envpol.2011.09.006

The National Development and Reform Commission. The People's Republic of China National Greenhouse Gas Inventory in 2005. China Environmental Science Press.

Tian, H., Chen, G., Lu, C., Xu, X., Hayes, D. J., Ren, W., ... Wofsy, S. C. (2015). North American terrestrial $\mathrm{CO}_{2}$ uptake largely offset by $\mathrm{CH}_{4}$ and $\mathrm{N}_{2} \mathrm{O}$ emissions: toward a full accounting of the greenhouse gas budget. Climatic Change, 129(3-4), 413-426. https://doi.org/10.1007/s10584-014-1072-9

Tian, H., Lu, C., Ciais, P., Michalak, A. M., Canadell, J. G., Saikawa, E., ... Wofsy, S. C. (2016). The terrestrial biosphere as a net source of greenhouse gases to the atmosphere. Nature, 531(7593), 225-228. https://doi.org/10.1038/nature16946

Tian, H., Yang, J., Lu, C., Xu, R., Canadell, J. G., Jackson, R. B., ... Zhu, Q. (2018). The Global $\mathrm{N}_{2} \mathrm{O}$ Model Intercomparison Project. Bulletin of the American Meteorological Society, 99(6), 1231-1251. https://doi.org/10.1175/BAMS-D-17-0212.1 
707 Tian, H., Yang, J., Xu, R., Lu, C., Canadell, J. G., Davidson, E. A., ... \& Gerber, S. (2019). Global soil nitrous oxide emissions since the preindustrial era estimated by an ensemble of terrestrial biosphere models: Magnitude, attribution, and uncertainty. Global Change Biology, 25(2), 640-659. https://doi.org/10.1111/gcb.14514

USEPA (2012). Global Anthropogenic Non-CO $\mathrm{C}_{2}$ Greenhouse Gas Emissions : 1990 - 2030. Office of Atmospheric Programs Climate Change Division U.S. Environmental Protection Agency. https://doi.org/EPA 430-R-12-006

Van Drecht, G., Bouwman, A. F., Knoop, J. M., Beusen, A. H. W., \& Meinardi, C. R. (2003). Global modeling of the fate of nitrogen from point and nonpoint sources in soils, groundwater, and surface water. Global Biogeochemical Cycles, 17(4), 1115. https://doi.org/10.1029/2003GB002060

Vet, R., Artz, R. S., Carou, S., Shaw, M., Ro, C. U., Aas, W., ... Reid, N. W. (2014). A global assessment of precipitation chemistry and deposition of sulfur, nitrogen, sea salt, base cations, organic acids, acidity and $\mathrm{pH}$, and phosphorus. Atmospheric Environment, 93, 3100. https://doi.org/10.1016/j.atmosenv.2013.10.060

Wang, R., Goll, D., Balkanski, Y., Hauglustaine, D., Boucher, O., Ciais, P., ... Tao, S. (2017). Global forest carbon uptake due to nitrogen and phosphorus deposition from 1850 to 2100 . Global Change Biology, 23(11), 4854-4872. https://doi.org/10.1111/gcb.13766

Wang, S., Luo, S., Li, X., Yue, S., Shen, Y., \& Li, S. (2016). Effect of split application of nitrogen on nitrous oxide emissions from plastic mulching maize in the semiarid Loess Plateau. Agriculture, Ecosystems and Environment, 220, 21-27. https://doi.org/10.1016/j.agee.2015.12.030

Winiwarter, W., Höglund-Isaksson, L., Klimont, Z., Schöpp, W., \& Amann, M. (2018). Technical opportunities to reduce global anthropogenic emissions of nitrous oxide. Environmental Research Letters, 13(1), 014011. https://doi.org/10.1088/1748- 
732

733

734

735

736

737

738

739

740

741

742

743

744

745

746

747

748

749

750

751

752

753

754

755

756

9326/aa9ec9

Xia, L., Lam, S. K., Wolf, B., Kiese, R., Chen, D., \& Butterbach-Bahl, K. (2018). Trade-offs between soil carbon sequestration and reactive nitrogen losses under straw return in global agroecosystems. Global Change Biology, 24(12), 5919-5932. https://doi.org/10.1111/gcb.14466

Yue, Q., Cheng, K., Ogle, S., Hillier, J., Smith, P., Abdalla, M., ... \& Pan, G. (2019). Evaluation of four modelling approaches to estimate nitrous oxide emissions in China's cropland. Science of the Total Environment, 652, 1279-1289. https://doi.org/10.1016/j.scitotenv.2018.10.336

Yue, Q., Ledo, A., Cheng, K., Albanito, F., Lebender, U., Sapkota, T. B., ... \& Pan, G. (2018). Re-assessing nitrous oxide emissions from croplands across Mainland China. Agriculture, Ecosystems and Environment, 268, 70-78. https://doi.org/10.1016/j.agee.2018.09.003

Zaehle, S., \& Friend, A. D. (2010). Carbon and nitrogen cycle dynamics in the O-CN land surface model: 1 . Model description, site-scale evaluation, and sensitivity to parameter estimates. Global Biogeochemical Cycles, 24(1), GB1005. https://doi.org/10.1029/2009GB003521

Zhang, B., Tian, H., Lu, C., Dangal, S. R. S., Yang, J., \& Pan, S. (2017). Global manure nitrogen production and application in cropland during 1860-2014: A 5 arcmin gridded global dataset for Earth system modeling. Earth System Science Data, 9(2), 667-678. https://doi.org/10.5194/essd-9-667-2017

Zhang, Y. L., Fan, J. B., Wang, D. S., \& Shen, Q. R. (2009). Genotypic Differences in Grain Yield and Physiological Nitrogen Use Efficiency Among Rice Cultivars. Pedosphere, 19(6), 681-691. https://doi.org/10.1016/S1002-0160(09)60163-6

Zhou, F., Shang, Z., Ciais, P., Tao, S., Piao, S., Raymond, P., ... \& Peng, S. (2014). A new high-resolution $\mathrm{N}_{2} \mathrm{O}$ emission inventory for China in 2008. Environmental science \& 

technology, 48(15), 8538-8547. https://doi.org/10.1021/es5018027

758 Zhou, F., Shang, Z., Zeng, Z., Piao, S., Ciais, P., Raymond, P. A., ... Mao, Q. (2015). New 759 model for capturing the variations of fertilizer-induced emission factors of $\mathrm{N}_{2} \mathrm{O}$. Global 760 Biogeochemical Cycles, 29(6), 885-897. https://doi.org/10.1002/2014GB005046

761 Zhu, X., Li, Y., Li, M., Pan, Y., \& Shi, P. (2013). Agricultural irrigation in China. Journal of 762 Soil and Water Conservation, 68(6), 147-154. https://doi.org/10.2489/jswc.68.6.147A

763 Zou, J., Lu, Y., \& Huang, Y. (2010). Estimates of synthetic fertilizer N-induced direct nitrous 764 oxide emission from Chinese croplands during 1980-2000. Environmental Pollution, $765 \quad 158(2), 631-635$. https://doi.org/10.1016/j.envpol.2009.08.026

766 Zuo, L., Zhang, Z., Carlson, K. M., MacDonald, G. K., Brauman, K. A., Liu, Y., ... \& Wang, 767 X. (2018). Progress towards sustainable intensification in China challenged by land-use 768 change. Nature Sustainability, 1(6), 304-313. https://doi.org/10.1038/s41893-018-0076-2 